\title{
EFFECT OF MAGNESIUM NUTRITION OF ONION (Allium cepa L.). PART I. YIELDING AND NUTRIENT STATUS
}

\author{
WPŁYW NAWOŻENIA MAGNEZEM CEBULI (Allium cepa L.) \\ CZEŚŚC I. PLONOWANIE I STAN ODŻYWIENIA
}

\begin{abstract}
Magnesium (Mg) serves specific physiological functions in plants, as it participates in $250 \div 400$ processes and may not be replaced by other elements, even those exhibiting similar physicochemical properties, such as $\mathrm{Co}^{2+}, \mathrm{Mn}^{2+}$ or $\mathrm{Ni}^{2+}$. The aim of the conducted studies was to optimize magnesium nutrition of onion (Allium cepa L.), through the evaluation of yielding of plants, and to determine its effect on contents of the following elements in leaves and bulbs: nitrogen $(\mathrm{N})$, phosphorus $(\mathrm{P})$, potassium $(\mathrm{K})$, calcium $(\mathrm{Ca})$ and magnesium (Mg). Magnesium was applied in the quick-acting form, $\mathrm{MgSO}_{4} \cdot 7 \mathrm{H}_{2} \mathrm{O}$, based on the chemical analyses of soil, in doses corresponding to $50,100,150$ and $200 \mathrm{mg} \mathrm{Mg} \cdot \mathrm{dm}^{-3}$ soil. The other nutrients were supplemented to standard levels recommended for the cultivation of onion, amounting to (in $\mathrm{mg} \cdot \mathrm{dm}^{-3} \mathrm{soil}$ ) $150 \mathrm{~N}$, $80 \mathrm{P}$ and $200 \mathrm{~K}$. Magnesium nutrition was found to have a positive effect on yielding of onion and its quality. Significantly the highest total yield $\left(4.85 \mathrm{~kg} \cdot \mathrm{m}^{-2}\right)$ and merchantable yield $\left(4.78 \mathrm{~kg} \cdot \mathrm{m}^{-2}\right)$ were obtained when applying Mg-100, which amounted to an increase by $38 \%$ and $45 \%$ in comparison with the control combination. Plant nutrition with magnesium in case of leaves significantly affected an improvement of their nutrient status for nitrogen, deterioration of calcium nutrition, while in case of leaves and bulbs that of potassium. Analyzed levels of magnesium nutrition had a significant effect on nutrient status of leaves and bulbs for this nutrient. Leaves accumulated more nitrogen, potassium, calcium and magnesium than bulbs. Controlled magnesium nutrition of plants is an effective method of biofortification of onion with this nutrient.
\end{abstract}

Keywords: magnesium, onion, yielding, macroelements, chlorophyll

Magnesium (Mg), similarly as the other metallic nutrients, is contained in soil in 3 fractions: exchangeable, inexchangeable and water soluble [1]. The inexchangeable fraction is composed of magnesium contained in primary and secondary minerals, including those of different hydration rates [2]. In turn, the exchangeable fraction of this nutrient typically accounts for approx. 5\% total magnesium content in soil and from 4 to $20 \%$ cation exchange capacity of soil. Magnesium is an important and essential macronutrient for the

\footnotetext{
${ }^{1}$ Department of Plant Nutrition, University of Life Sciences in Poznan, ul. Zgorzelecka 4, 60-199 Poznań, Poland, email: ag@up.poznan.pl

${ }^{2}$ Department of Vegetable Crops, University of Life Sciences in Poznan, ul. Dąbrowskiego 159, 60-594 Poznań, Poland, email: brassica@up.poznan.pl

* Corresponding author: tkleiber@up.poznan.pl
} 
proper development and functioning of living organisms. It participates in the regulation of many biochemical processes, first of all being involved in the appropriate functioning of the brain in animals and humans. It is also a component of systemic fluids and bones. In case of plants magnesium (from 15 to $30 \%$ its total contents) is bound in chlorophyll molecules [3, 4]. It is estimated that magnesium in $75 \div 80 \%$ serves the function of a co-factor in many enzymatic processes, connected eg with phosphorylation, dephosphorylation, as well as hydrolysis of different compounds, and what is more it stabilizes the structure of different nucleotides [1]. Magnesium requirement of plants to a considerable degree depends on the pool of available forms of this nutrient in the soil. It usually amounts to 1 to over $20 \mathrm{mg} \mathrm{Mg} \cdot 100 \mathrm{~g}$ soil. Magnesium is absorbed by plants in the form of the $\mathrm{Mg}^{2+}$ cation, but similarly as calcium $(\mathrm{Ca})$, as a mobile element is may be leached, particularly in case of light soils, deeper into the soil profile by precipitation waters, which as a consequence contributes also to the consistent acidification of soil and poses a threat of insufficient nutrition of plants with this nutrient. In case of insufficient contents of magnesium in soil plants may transport this nutrient through the phloem to their actively growing, juvenile parts [1], which may result in the appearance of characteristic symptoms of magnesium interveinal chlorosis. Additional environmental factors affecting the potential occurrence of symptoms of magnesium deficit in plants include drought or irregular water availability [5, 6], low temperature $[7,8]$ or low $\mathrm{pH}$ of soil [9-11].

Garden onion (Allium cepa L.) is a vegetable of high economic importance. This species is grown in at least 175 countries. According to the United Nations Food and Agriculture Organization the cropped area is estimated at 2.7 million hectares and production is assessed to be $45 \div 55$ million tons annually. The leading producers are China, India, the USA, Turkey and Pakistan [12]. Onion ranks second worldwide, after tomato, in terms of production among the 15 most important vegetable species, while it ranks $5^{\text {th }}$ in Poland in terms of the level of consumption $[13,14]$. Mean onion consumption per capita in Europe ranges from 7 to $8 \mathrm{~kg}$, while in Poland it is $7.2 \mathrm{~kg}$ [15].

The aim of these studies was to optimize magnesium nutrition of onion (Allium cepa L.) in order to obtain the best yielding, both in terms of its quality and quantity, and to determine its effect on the contents of nitrogen, phosphorus, potassium, calcium and magnesium (in leaves and bulbs) and chlorophyll (in leaves). Biofortification of onion with magnesium is important due to the volume of consumption of this vegetable worldwide and the potential enrichment of daily diet with this nutrient.

\section{Material and methods}

The vegetation experiments were conducted in the region famous for the production of high quality field vegetable crops (central Poland). The experiments were established in the belt-row system, in four replications, on soil poor in magnesium using a heterosis onion cultivar 'Solution $F_{1}$ ' (Syngenta). On a bed of $135 \mathrm{~cm}$ in width (and $300 \mathrm{~cm}$ in length) there were 4 rows of plants $(22.5 \mathrm{~cm}$ apart). Single-grain sowing was applied (in mid-April) in rows at $4 \mathrm{~cm}$ apart, ie 375 seeds per bed $=92.6$ seeds per $1 \mathrm{~m}^{2}$, which gave at an average germinability of $85 \%$ - a density of 78.6 plants per $1 \mathrm{~m}^{2}$ (ie 786 thousand plants per 1 hectare).

Prior to the establishment of the experiments soil samples were collected from the layer of the main accumulation of root systems $(0 \div 20 \mathrm{~cm})$. The collected samples of soils were 
chemically analysed by the universal method of Nowosielski [16]. Extraction of macroelements $\left(\mathrm{N}-\mathrm{NH}_{4}, \mathrm{~N}-\mathrm{NO}_{3}, \mathrm{P}, \mathrm{K}, \mathrm{Ca}, \mathrm{Mg}, \mathrm{S}-\mathrm{SO}_{4}\right), \mathrm{Cl}$ and $\mathrm{Na}$ was carried out in $0.03 \mathrm{M} \mathrm{CH}{ }_{3} \mathrm{COOH}$. After extraction, $\mathrm{N}_{-} \mathrm{NH}_{4}, \mathrm{~N}-\mathrm{NO}_{3}$ were determined by microdistillation according to Bremner in Starck's modification, $\mathrm{P}$ was colorimetrically analysed with ammonium vanadomolibdate; $\mathrm{K}, \mathrm{Ca}, \mathrm{Na}$ - with the use of photometry; $\mathrm{Mg}$ by atomic absorption spectrometry (AAS, on Carl Zeiss Jena - apparatus); $\mathrm{S}_{-} \mathrm{SO}_{4}$ nephelometrically with $\mathrm{BaCl}_{2} ; \mathrm{Cl}$ - nephelometrically with $\mathrm{AgNO}_{3}$. Microelements $(\mathrm{Fe}, \mathrm{Mn}$, $\mathrm{Zn}$ and $\mathrm{Cu}$ ) were extracted from soil using Lindsay's solution (containing in $10 \mathrm{dm}^{3}: 50 \mathrm{~g}$ of EDTA (ethylenediaminetetraacetic acid), $90 \mathrm{~cm}^{3}$ of $25 \% \mathrm{NH}_{4} \mathrm{OH}$ solution, $40 \mathrm{~g}$ of citric acid, $20 \mathrm{~g}$ of $\left.\mathrm{Ca}\left(\mathrm{CH}_{3} \mathrm{COO}\right)_{2} \cdot 2 \mathrm{H}_{2} \mathrm{O}\right)$ and then, they were determined by AAS method. Salination was analysed by conductometric method (electric conductivity EC in $\left[\mathrm{mS} \cdot \mathrm{cm}^{-1}\right]$ ). Reaction $\mathrm{pH}$ was measured potentiometrically (soil : water proportion $=1: 2$ ) [17].

Mean chemical composition of soil prior to seed sowing was as follows (in $\left[\mathrm{mg} \cdot \mathrm{dm}^{-3}\right]$ ): $\mathrm{N}-\mathrm{NH}_{4} 4, \mathrm{~N}_{-} \mathrm{NO}_{3}$ traces, $\mathrm{P}-\mathrm{PO}_{4}$ 36, K 38, Ca 209, Mg 12, S-SO 4 traces, Fe 55.4, Mn 18.1, $\mathrm{Zn} \mathrm{3,} \mathrm{Cu} 1.55, \mathrm{Na} 13, \mathrm{Cl} 45 ; \mathrm{pH}$ in $\mathrm{H}_{2} \mathrm{O} 6.35$, EC $\left[\mathrm{mS} \cdot \mathrm{cm}^{-1}\right.$ ] 0.05. Plant fertilization was developed by supplementing the nutrients found in inadequate amounts to guide values recommended for onion growing [18-20]. In the conducted experiments the control comprised the natural soil magnesium levels. In the analyzed combinations the level of magnesium in the soil was diversified, using (in $\left[\mathrm{mg} \cdot \mathrm{dm}^{-3}\right.$ soil]) the amounts of 50,100 , 150 and $200 \mathrm{Mg}$ (denoted as $\mathrm{Mg}-50, \mathrm{Mg}-100, \mathrm{Mg}-150$ and $\mathrm{Mg}-200$, respectively, which corresponds to magnesium doses of 10,20, 30 and $40 \mathrm{~g} \mathrm{Mg} \cdot \mathrm{m}^{-2}$ ), applying the investigated nutrient in the quick-acting form of $\mathrm{MgSO}_{4} \cdot 7 \mathrm{H}_{2} \mathrm{O}$. The other macro- and micronutrients, which constituted the background for the experiment, were supplemented to standard levels. The following were applied (in [mg $\cdot \mathrm{dm}^{-3}$ soil]): $150 \mathrm{~N}$ in the form of ammonium nitrate in two doses ( $1 / 2$ before sowing and the other $1 / 2$ at the phase of $1-3$ fully developed leaves). The other nutrients were applied once to the interrows in the early spring (in [mg. $\mathrm{dm}^{-3}$ soil]): $80 \mathrm{P}$ as ammonium phosphate and $\mathrm{K}-200$ in the form of potassium sulfate.

Towards the end of August - at the phase of harvest ripeness - a single harvest of the aboveground parts was performed and the yield of fresh weight of bulbs and the level of commercial yield were determined. Leaves and bulbs were dried at $45 \div 50^{\circ} \mathrm{C}$ and then ground. In order to assay total forms of nitrogen, phosphorus, potassium, magnesium and calcium plant material was mineralized in concentrated sulfuric acid. After mineralization of plant material the following determinations were performed: $\mathrm{N}$ - using the distillation method according to Kjeldahl in a Parnas-Wagner apparatus; P - by colorimetry with

ammonium molybdate; $\mathrm{K}, \mathrm{Ca}$ and $\mathrm{Mg}$ using atomic absorption spectroscopy (AAS); (in a Carl Zeiss Jena apparatus; Thornwood, NY, USA). The relative content of chlorophyll in leaves was measured with the use of a SPAD 506 device (by Minolta). Results of biometric measurements and chemical analyses were subjected to statistical analyses, with inference at the significance level $\mathrm{p}=0.05$.

\section{Results and discussion}

\section{Yielding}

Analyzed magnesium levels (in the range of Mg-50 to Mg-200) resulted in a significant increase in total and commercial yields of bulbs in relation to the control (Fig. 1). Significantly the highest total yield $\left(4.85 \mathrm{~kg} \cdot \mathrm{m}^{2}\right)$ and commercial yield $\left(4.78 \mathrm{~kg} \cdot \mathrm{m}^{2}\right)$ were 
obtained at magnesium content in soil amounting to $100 \mathrm{mg} \mathrm{Mg} \cdot \mathrm{dm}^{-3}$ (Mg-100), which constituted an increase in yielding by approximately $38 \%$ and $45 \%$ in comparison with the control combination. Magnesium nutrition of onion at a dose of Mg-150 resulted in a significant reduction of total and commercial yields by $12.5 \%$ in relation to the level of Mg-100. Yielding of onion in case of magnesium nutrition levels (Mg-50, Mg-150 and Mg-200) did not differ significantly.

The optimal content of magnesium in onion growing is lower than that recorded in the analyses conducted by the authors of the study and it amounts to $50 \div 60 \mathrm{mg} \mathrm{Mg} \mathrm{[21].}$ In turn, other sources [15] reported a wider range from 50 to $80 \mathrm{mg} \mathrm{Mg} \cdot \mathrm{dm}^{-3}$ soil as optimal and Nowosielski [22] gave $50 \div 100 \mathrm{mg} \mathrm{Mg} \mathrm{dm}^{-3}$ soil. Adamicki et al [23] proposed the range from 50 to $130 \mathrm{mg} \mathrm{Mg} \cdot \mathrm{dm}^{-3}$ soil, within which the results of this study exhibited a significant variation in yielding of plants. It results from the experiments conducted by the above-mentioned authors [23] that magnesium content of $130 \mathrm{mg} \mathrm{Mg} \mathrm{dm}^{-3}$ soil contributes to a deterioration of plant yielding.

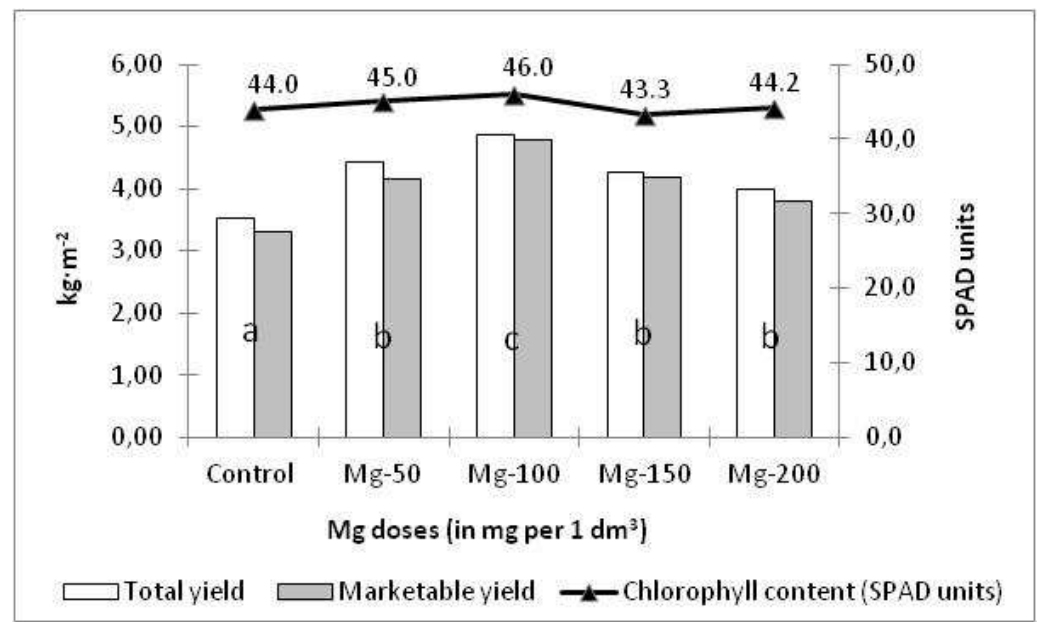

Fig. 1. The effect of plant nutrition with magnesium on total and commercial yields as well as relative chlorophyll content in leaves

Increasing the magnesium levels in soil results in an increase of contents for total chlorophyll, soluble sugars and vitamin $C$ in leaves of garden onion and chives [24]. In the conducted analyses relative contents of chlorophyll determined in chives changed slightly under the influence of increasing magnesium nutrition of plants, falling within the range of 43.3 (Mg-150) to 46.0 (Mg-100). However, with an increase in magnesium nutrition a significant improvement was observed in the dry matter contents in leaves, which may be of importance due to the keeping quality of onion.

\section{Chemical analyses of plants}

In the conducted investigations magnesium was applied at doses ranging from 50 to $200 \mathrm{mg} \mathrm{Mg} \cdot \mathrm{dm}^{-3}$. Irrespective of the applied magnesium dose, mean contents of nitrogen in bulbs of onion were over two times lower than in leaves (Table 1). The highest amounts 
of nitrogen were accumulated by bulbs in the Mg-50 combination, while for leaves it was in case of $\mathrm{Mg}-200$, whereas in the control combination, with no magnesium fertilization, the lowest nitrogen content was determined in the above-mentioned organs. In case of phosphorus a marked synergism was found between the content of phosphorus in leaves and plant nutrition with magnesium, at the simultaneous slightly lower accumulation of phosphorus in bulbs. Mean contents of phosphorus, both in leaves and bulbs, were identical (at $0.28 \% \mathrm{P}$ in d.m. each). In turn, a significant antagonistic effect of the increasing magnesium nutrition of plants was found on a reduction of potassium both in bulbs and leaves. Recorded contents of this nutrient in leaves were on average 2.8 times bigger than in case of bulbs. Increasing nutrition with magnesium resulted in significant changes in calcium contents both in leaves and bulbs, while in leaves its content was reduced and in bulbs (in case of $\mathrm{Mg}-100$ and $\mathrm{Mg}$-200) calcium content increased.

A consistent increase in the contents of magnesium, both in leaves and bulbs of onion, was found when applying magnesium in the fertilization to the level of $\mathrm{Mg}-150$, but its highest dose $(\mathrm{Mg}-200)$ resulted in a reduction of the contents of this macronutrient in both analyzed parts of plants. On average leaves accumulated over 2.5 times more magnesium than bulbs of onion.

Magnesium is an element exhibiting multifaceted effects on the environment [25]. It modifies yielding capacity of plants, ionic equilibrium of plants as well as chemical and microbiological properties of soil. Rational fertilization with magnesium may have a positive effect on all the above-mentioned elements.

Table 1

The effect of magnesium nutrition on contents of nitrogen, phosphorus, potassium, calcium and magnesium [\% in d.m.] and dry matter [\% of DM]

\begin{tabular}{|c|c|c|c|c|c|c|}
\hline Mg level [mg Mg. $\mathrm{dm}^{-3}$ ] & $\mathbf{N}$ & $\mathbf{P}$ & $\mathbf{K}$ & $\mathbf{C a}$ & Mg & [\% of DM] \\
\hline \multicolumn{7}{|c|}{ Leaves } \\
\hline Control & $2.92 \mathrm{a}$ & $0.24 \mathrm{a}$ & $5.04 \mathrm{~b}$ & $3.96 \mathrm{a}$ & $0.49 a$ & $13.3 \mathrm{a}$ \\
\hline $\mathrm{Mg}-50$ & $3.04 \mathrm{c}$ & $0.30 \mathrm{a}$ & $5.07 \mathrm{~b}$ & $3.30 \mathrm{~b}$ & $0.54 \mathrm{a}$ & $13.7 \mathrm{a}$ \\
\hline $\mathrm{Mg}-100$ & $2.99 \mathrm{~b}$ & $0.25 \mathrm{a}$ & $4.74 \mathrm{a}$ & $3.16 \mathrm{~b}$ & $0.69 \mathrm{~b}$ & $14.2 \mathrm{a}$ \\
\hline $\mathrm{Mg}-150$ & $3.04 \mathrm{c}$ & $0.28 \mathrm{a}$ & $4.79 \mathrm{a}$ & $3.67 \mathrm{ab}$ & $0.93 \mathrm{c}$ & $17.5 \mathrm{a}$ \\
\hline $\mathrm{Mg}-200$ & $3.32 \mathrm{~d}$ & $0.30 \mathrm{a}$ & $4.44 \mathrm{a}$ & $2.71 \mathrm{c}$ & $0.77 \mathrm{c}$ & $16.3 \mathrm{a}$ \\
\hline Mean & 3.06 & 0.27 & 4.82 & 3.36 & 0.68 & 15.0 \\
\hline Mean for Mg-50 - Mg-200 & 3.10 & 0.28 & 4.76 & 3.21 & 0.73 & 15.4 \\
\hline \multicolumn{7}{|c|}{ Bulbs } \\
\hline Control & $1.34 \mathrm{a}$ & $0.30 \mathrm{a}$ & $1.92 \mathrm{~b}$ & $0.62 \mathrm{a}$ & $0.23 \mathrm{a}$ & $15.9 \mathrm{a}$ \\
\hline $\mathrm{Mg}-50$ & $1.54 \mathrm{a}$ & $0.28 \mathrm{a}$ & $1.68 \mathrm{a}$ & $0.57 \mathrm{a}$ & $0.24 \mathrm{a}$ & $15.1 \mathrm{a}$ \\
\hline $\mathrm{Mg}-100$ & $1.43 \mathrm{a}$ & $0.27 \mathrm{a}$ & $1.68 \mathrm{a}$ & $0.72 \mathrm{a}$ & $0.27 \mathrm{ab}$ & $14.6 \mathrm{a}$ \\
\hline $\mathrm{Mg}-150$ & $1.41 \mathrm{a}$ & $0.29 \mathrm{a}$ & $1.70 \mathrm{a}$ & $0.48 \mathrm{a}$ & $0.29 \mathrm{~b}$ & $15.0 \mathrm{a}$ \\
\hline $\mathrm{Mg}-200$ & $1.41 \mathrm{a}$ & $0.29 \mathrm{a}$ & $1.64 \mathrm{a}$ & $0.67 \mathrm{a}$ & $0.25 \mathrm{a}$ & $14.2 \mathrm{a}$ \\
\hline Mean & 1.43 & 0.29 & 1.72 & 0.61 & 0.26 & 15.0 \\
\hline Mean for Mg-50 - Mg-200 & 1.45 & 0.28 & 1.68 & 0.61 & 0.26 & 14.7 \\
\hline
\end{tabular}

Values designated with the same letters in columns do not significantly differ at $\mathrm{p}=0.05$

Irrespective of the level of magnesium nutrition the mean contents of total nitrogen in the conducted analyses $(1.41 \% \mathrm{~N}$ in d.m.) were smaller than the mean for 21 cultivars of that species $(2.28 \% \mathrm{~N}$ in d.m.) analyzed by Kleiber et al [26], those of phosphorus $(0.48 \% \mathrm{P}$ in d.m.), potassium $(1.95 \% \mathrm{~K}$ in d.m.) or calcium $(2.00 \% \mathrm{Ca})$. Only in case 
of magnesium the mean contents of this nutrient were higher than those reported in earlier studies [26]. Nitrogen contents found in this study in bulbs fell within the range reported earlier for the contents of this nutrient [27]. In all the analyzed combinations the contents of nitrogen in bulbs exceeded $1 \% \mathrm{~N}$ in d.m., which indicates adequate nutrition with this nutrient $[28,29]$, markedly higher contents of phosphorus, at the simultaneous deterioration of nutrition with potassium, calcium and magnesium [27]. Also markedly lower contents of magnesium in bulbs were reported by Tahvonen [30]. In turn, considerably lower contents of nitrogen in bulbs (on average $2.34 \% \mathrm{~N}$ in d.m.), similar for phosphorus $(0.33 \% \mathrm{P}$ in d.m.) and potassium $(1.46 \% \mathrm{~K}$ in d.m.), at the simultaneous markedly worse nutrition with calcium (at average $0.13 \% \mathrm{Ca}$ in d.m.) and magnesium (0.05\% $\mathrm{Mg}$ in d.m.), were reported by Blazewicz-Wozniak et al [31].

The effect of magnesium in the accumulation of other nutrients is dependent on the species, plant organ and only to a slight degree on the manner of its application [25]. Literature sources report on interactions occurring between magnesium and the following elements: nitrogen [32-35], phosphorus [32, 36-39], potassium [32, 40] and calcium [41-44]. There is a positive synergistic effect of plant nutrition with magnesium on the accumulation of nitrogen in plants [45], which is confirmed by the determinations of relationships between these nutrients in case of onion leaves. In turn, magnesium and potassium as two cations acting strongly antagonistically may significantly reduce their mutual uptake by plants. This phenomenon was also documented in this study, as increasing magnesium nutrition of plants was accompanied by a significant reduction of potassium content in leaves. A similar phenomenon is observed in case of the antagonism between calcium and magnesium. In the analyses conducted by the authors of this study a significant reduction was shown for the uptake of calcium cations by leaves, with an increase in the intensity of plant nutrition with magnesium. A synergistic tendency was shown (in case of leaves) for the improvement of plant nutrition with phosphorus, occurring as a result of an improved nutrition of plants with magnesium, which confirms opinions held in this respect [32].

\section{Conclusions}

Conducted analyses aimed at the optimization of nutrition of onion (Allium cepa L.) with magnesium. Nutrition of plants with this nutrient had a synergistic effect on the nutrient status of leaves in case of nitrogen and phosphorus, a deterioration of calcium nutrition of leaves and that of leaves and bulbs with potassium. Analyzed levels of magnesium nutrition significantly modified contents of this nutrient in leaves and bulbs. Leaves accumulated more (means in [\%]) $\mathrm{N}-114, \mathrm{~K}-180.2, \mathrm{Ca}-450.8$ and $\mathrm{Mg}-161.5$ than bulbs. Increasing magnesium nutrition levels did not have a significant effect on relative contents of chlorophyll in leaves. A positive effect of the analyzed nutrient was found on yielding of onion and its quality. Significantly highest total and commercial yields were obtained when using $100 \mathrm{mg} \mathrm{Mg} \cdot \mathrm{dm}^{-3}$ soil, which constituted an increase by $38 \%$ and $45 \%$ in comparison with the control combination. The best yielding of plants was obtained at the following contents of nutrients in leaves (in [\% in d.m.]): $\mathrm{N} \mathrm{2.99,} \mathrm{P} \mathrm{0.25,} \mathrm{K} \mathrm{4.74,}$ $\mathrm{Ca} 3.16, \mathrm{Mg} 0.69$ and in bulbs (in [\% in d.m.]): N 1.43, P 0.27, K 1.68, Ca 0.72 and $\mathrm{Mg}$ 0.27 . These contents are proposed as guide values for onion. Controlled magnesium nutrition of plants is an effective method of biofortification of onion with this nutrient. 


\section{References}

[1] Barker AV, Pilbeam DJ. Handbook of Plant Nutrition. Boca Raton: Taylor \& Francis Group; 2007, 146-181. DOI: 10.1201/9781420014877.fmatt.

[2] Kirkby EA, Mengel K. The role of magnesium in plant nutrition. Z Pflanzenern Bodenk. 1976;2:209-222.

[3] Marschner H. Mineral Nutrition of Higher Plants. $2^{\text {nd }}$ ed. New York: Academic Press; 1995.

[4] Neales TF. Components of the total magnesium content within the leaves of white clover and perennial rye grass. Nature. 1956;177:388-389. DOI: 10.1038/177388a0.

[5] Huang B. Nutrient accumulation and associated root characteristics in response to drought stress in tall fescue cultivars. Hort Science. 2001;36(1):148-152. DOI: 35400009866683.0380.

[6] Kolb TE, McCormick LH. Etiology of sugar maple decline in four Pennsylvania stands. Can J Forest Res. 1993;23(11):2395-2402. DOI: 10.1139/x93-296.

[7] Huang JW, Grunes DL. Effects of root temperature and nitrogen form on magnesium uptake and translocation by wheat seedlings. J Plant Nutr. 1992;15(6/7):991-1005.

[8] Jensén P, Perby J. Growth and accumulation of $\mathrm{N}, \mathrm{K}^{+}, \mathrm{Ca}^{2+}$, and $\mathrm{Mg}^{2+}$ in barley exposed to various nutrient regimes and root/shoot temperatures. Physiol Plant. 1986;67:159-165. DOI: 10.1111/j.1399-3054.1986.tb02438.x.

[9] Marier TE. Solution pH influences on growth and mineral element concentrations of 'Waimanalo' papaya seedlings. J Plant Nutr. 1998;212:601-2612. DOI: 10.1080/01904169809365591.

[10] Melakeberhan H, Jones AL, Bird GW. Effects of soil pH and Pratylenchus penetrans on the mortality of 'Mazzard' cherry seedlings and their susceptibility to Pseudomonas syringae pv. syringae. Can. J Plant Pathol. 2000;22:131-137. DOI: 10.1080/07060660009500486.

[11] Tan KZ, Keltjens WG, Findenegg GR. Acid soil damage in sorghum genotypes - role of magnesium - deficiency and root impairment. Plant Soil. 1992;139(2):149-155. DOI: 10.1007/BF00009305.

[12] http://www.onions-usa.org/contact/contact.php [cited 2010.12.17].

[13] Niemirowicz-Szczytt K. Hodowla roślin warzywnych. Warszawa: SGGW; 1993 (in Polish).

[14] Skąpski H, Dąbrowska B. Uprawa warzyw w polu. Warszawa: SGGW; 1994 (in Polish). ISBN 83-00-02846-3.

[15] Rumpel J. Uprawa cebuli. Warszawa: Hortpress; 2000 (in Polish).

[16] Nowosielski O. Metody oznaczania potrzeb nawożenia. Warszawa: PWRiL; 1974, 1-91 (in Polish).

[17] IUNG. Metody badań laboratoryjnych w stacjach chemiczno-rolniczych. Cz. III. Badanie gleb, ziem i podłoży spod warzyw i kwiatów oraz części wskaźnikowych roślin w celach diagnostycznych. Puławy: IUNG; 1983, 28-81 (in Polish).

[18] Sady W. Nawożenie warzyw polowych. Warszawa: Plantpress; 2000, 8-33 (in Polish).

[19] Metodyka Integrowanej Produkcji Cebuli. Warszawa: Państwowa Inspekcja Ochrony Roślin i Nasiennictwa; 2005, 1-38 (in Polish).

[20] Breś W, Golcz A, Komosa A, Kozik E, Tyksiński W. Nawożenie roślin ogrodniczych. Poznań: Wydawnictwo Uniwersytetu Przyrodniczego w Poznaniu; 2008, 5-189 (in Polish). ISBN 978-83-7160-548-2.

[21] Dobrzański A, Adamicki F. Uprawa cebuli. Kraków: Plantpress; 2006 (in Polish).

[22] Nowosielski O. Znaczenie potasu i magnezu w uprawie roślin ogrodniczych. In: Materiały na Konferencję Ogólnopolską. Skierniewice: Instytut Warzywnictwa; 1994, 9-13 (in Polish).

[23] Adamicki F, Dobrzański A. Cebula. Technologia uprawy i przechowywania. Skierniewice: Instytut Warzywnictwa; 1999 (in Polish).

[24] Gurgul E, Kołota E, Herman B, Biczak R. The effect of magnesium and potassium fertilization on chlorophyll, sugars and ascorbic acid contents of onion and chive leaves. Zesz Nauk AR we Wrocławiu. 1998; Rolnictwo LXXIII, 347:155-164; ISSN 0137-1959.

[25] Wyszkowski M. Effect of magnesium on yield formation and the mutual relations between some ions in crops. Olsztyn: Rozpr Monograf UW-M; 2001, 52.

[26] Kleiber T, Bosiacki M, Markiewicz B. Effect of the controlled fertilization on the mineral components of chosen varieties of onion (Allium cepa L.). Part I. Macroelements. Ecological Chemistry and Engineering. 2010;17(2-3):269-278. ISSN 1898-6188.

[27] Coolong TW, Kopsell DA, Kopsell DE, Randle WM. Nitrogen and sulfur influence nutrient usage and accumulation in onion. J Plant Nutr. 2004;27(9):1667-1686. DOI: 10.1081/PLN-200026010.

[28] Zink FW. Studies on the growth rate and nutrient absorption of onion. Hilgardia. 1966;37(8):203-218.

[29] Mills HA, Jones Jr. JB. Plant Analysis Handbook. II. Athens (GA): MicroMacro Publishing Inc.; 1996, 6-62. 
[30] Tahvonen R. Contents of selected elements in some fruits, berries and vegetables on the Finnish market in 1987-1989. J Food Comp Anal. 1993;6:75-86. DOI: 10.1006/jfca.1993.1009.

[31] Błażewicz-Woźniak M, Kęsik T, Wach D, Konopiński M. The influence of conservation tillage on the mineral elements content in soil and chemical composition of onion. Acta Sci Pol Hortorum Cultus. 2008;7(2):61-72. ISSN 1644-0692.

[32] Lasa B, Frechilla S, Aleu M, González-Moro B, Lamsfus C, Aparicio-Tejo PM. Effects of low and high levels of magnesium on the response of sunflower plants grown with ammonium and nitrate. Plant Soil. 2000;225:167-174. DOI: 10.1023/A:1026568329860.

[33] Puech L, Mehne-Jakobs B. Histology of magnesium-deficient Norway spruce needles influenced by nitrogen source. Tree Physiol. 1997;17(5):301-310. DOI: 10.1093/treephys/17.5.301.

[34] Wilcox GE, Hoff JE, Jones CM. Ammonium reduction of Ca and Mg content of tomato and sweetcorn leaf tissue and influence on incidence of blossom end root of tomato fruit. J Amer Soc Hort Sci. 1973;98:86-89.

[35] Chance III WO, Somda ZC, Mills HA. Effect of nitrogen form during the flowering period on zucchini squash growth and nutrient element uptake. J Plant Nutr. 1999;22:597-607. DOI: $0.1080 / 01904169909365655$.

[36] James DW, Hurst CJ, Tindall TA. Alfalfa cultivar response to phosphorus and potassium deficiency - Elemental composition of the herbage. J Plant Nutr. 1995;18(11):2447-2464. DOI: 10.1080/01904169509365076.

[37] Fageria NK, Zimmermann FJP, Baligar VC. Lime and phosphorus interactions on growth and nutrient uptake by upland rice, wheat, common bean, and corn in an oxisol. J Plant Nutr. 1995;18(11):2519-2532. DOI: 10.1080/01904169509365081.

[38] Reinbott TM, Blevins DG. Phosphorus and temperature effects and magnesium, calcium, and potassium in wheat and tall fescue leaves. Agron J. 1994;86(3):523-529. DOI: 10.1080/01904169509365081.

[39] Reinbott TM, Blevins DG. Phosphorus nutritional effects on root hydraulic conductance, xylem water flow and flux of magnesium and calcium in squash plants. Plant Soil. 1999;209(2):263-273. DOI: $10.1023 / \mathrm{A}: 1004646732225$.

[40] Cao W, Tibbitts TW. Growth, carbon dioxide exchange and mineral accumulation in potatoes grown at different magnesium concentrations. J Plant Nutr. 1992;15(9):1359-1371. DOI: 10.1080/01904169209364403.

[41] Appenroth KJ, Gabrys H, Scheuerlein RW. Ion antagonism in phytochrome-mediated calciumdependent germination of turions of Spirodela polyrhiza (L.) Schleiden. Planta. 1999;208:583-587. DOI: $10.1007 / \mathrm{s} 004250050596$.

[42] Carvajal M, Martínez V, Cerdá A. Influence of magnesium and salinity on tomato plants grown in hydroponic culture. J Plant Nutr. 1999;22:177-190. DOI: 10.1080/01904169909365616.

[43] Hicklenton PR, Cairns KG. Calcium and magnesium nutrition of containerized Cotoneaster dammeri 'Coral Beauty'. J Environ Hort. 1992;10(2):104-107.

[44] Schwartz S, Bar-Yosef B. Magnesium uptake by tomato plants as affected by Mg and Ca concentration in solution culture and plant age. J Agron. 1983;75(2):267-272.

[45] Choudhury TMA, Khanif YM. Evaluation of effects of nitrogen and magnesium fertilization on rice yield and fertilizer nitrogen efficiency using $15 \mathrm{~N}$ tracer technique. J Plant Nutr. 2001;24(6),855-871. DOI: $10.1081 /$ PLN-100103778.

\title{
WPŁYW NAWOŻENIA MAGNEZEM CEBULI (Allium cepa L.) CZĘŚĆ I. PLONOWANIE I STAN ODŻYWIENIA
}

\author{
${ }^{1}$ Katedra Żywienia Roślin, Uniwersytet Przyrodniczy w Poznaniu \\ ${ }^{2}$ Katedra Warzywnictwa, Uniwersytet Przyrodniczy w Poznaniu
}

\begin{abstract}
Abstrakt: Magnez (Mg) pełni w roślinie specyficzne funkcje fizjologiczne - bierze udział w 250-400 procesach i nie może być zastąpiony przez inne pierwiastki, nawet o zbliżonych właściwościach fizykochemicznych, takie jak $\mathrm{Co}^{2+}, \mathrm{Mn}^{2+}$ czy Ni${ }^{2+}$. Celem prowadzonych badań była optymalizacja żywienia cebuli (Allium cepa $\mathrm{L}$.) magnezem poprzez ocenę plonowania roślin oraz jego wpływu na zawartość w liściach i cebulach: azotu $(\mathrm{N})$, fosforu $(\mathrm{P})$, potasu $(\mathrm{K})$, wapnia $(\mathrm{Ca})$ i magnezu $(\mathrm{Mg})$. Magnez zastosowano w formie szybko działającego $\mathrm{MgSO}_{4} \cdot 7 \mathrm{H}_{2} \mathrm{O}$, na podstawie analizy chemicznej gleby, w dawkach odpowiadających: 50, 100, 150, $200 \mathrm{mg} \mathrm{Mg} \cdot \mathrm{dm}^{-3}$ gleby. Pozostałe składniki pokarmowe uzupełniano do poziomów standardowych polecanych do
\end{abstract}


uprawy cebuli wynoszących (w mg. $\mathrm{dm}^{-3}$ gleby): $150 \mathrm{~N}, 80 \mathrm{P}, 200 \mathrm{~K}$. Stwierdzono pozytywny wpływ żywienia magnezem na plonowanie cebuli oraz jej jakość. Istotnie największy plon ogólny $\left(4,85 \mathrm{~kg} \cdot \mathrm{m}^{-2}\right)$ oraz handlowy $\left(4,78 \mathrm{~kg} \cdot \mathrm{m}^{-2}\right)$ uzyskano, stosując $\mathrm{Mg}-100$, co stanowiło wzrost o $38 \%$ i $45 \% \mathrm{w}$ porównaniu z kombinacją kontrolną. Żywienie roślin magnezem wpływało istotnie w przypadku liści na poprawę stanu ich odżywienia azotem, pogorszenie odżywienia wapniem - a w przypadku liści i cebuli - potasem. Badane poziomy żywienia magnezem wpływały istotnie na stan odżywienia liści i cebuli tym składnikiem. Liście gromadziły więcej azotu, potasu, wapnia i magnezu niż cebula. Kontrolowane żywienie roślin magnezem jest efektywną metodą biofortyfikacji cebuli w ten składnik.

Słowa kluczowe: magnez, cebula, plonowanie, makroelementy, chlorofil 